\title{
A twenty-five year transition. The forms of power and the alleged crisis of the nation-state in the contemporary age
}

\section{Beatrice Benocci*}

\section{ABSTRACT}

In the aftermath of the Soviet collapse, we witnessed the end of the idea of a division of the world between good and bad, between capitalists and proponents of the planned economy, between right and left, between pro-Communists and pro-Americans; and again, disappeared the need of so many emerging countries to define themselves as a "third block" as opposed to the bipolar system. The economic idea of a first, second and third world could have been considered overcome. The world was forced to re-read itself and to understand that it was necessary to start thinking about international relations in a completely different way.

Key words: Soft Power, Hard Power, Nation-State, Globalization

\section{RESUMEN}

Después del colapso soviético, fuimos testigos del fin de la idea de una división del mundo entre el bien y el mal, entre capitalistas y partidarios de la economía planificada, entre la derecha y la izquierda, entre procomunistas y proamericanos; y de nuevo desapareció la necesidad de tantos países emergentes de definirse como un "tercer bloque" frente al sistema bipo-

* Doctora en historia de las relaciones internacionales. Docente - Investigadora de Centro Studi Europei - Dipartimento di Scienze Politiche, Sociali e della Comunicazione - CSE-DSPSC, Università di Salerno, (Italia). [bbenocci@ unisa.it]

Recibido: 1 de mayo de 2018 / Modificado: 23 de julio de 2018 / Aceptado: 2 de agosto de 2018.

Para citar este artículo:

Benocci, B. (2018). A twenty-five year transition. The forms of power and the alleged crisis of the nation-state in the contemporary age OASIS, 28, pp. 7-24.

DOI: https://doi.org/10.18601/16577558.n28.02 
lar. La idea económica de un primer, segundo y tercer mundo podría haberse considerado superada. El mundo se vio obligado a releerse a sí mismo y a comprender que era necesario empezar a pensar en las relaciones internacionales de una manera completamente diferente.

Palabras clave: Soft Power, Hard Power, Estado-nación, globalización

\section{A Twenty-Five Year Transition}

\section{PREFACE}

John Nye states that Trump is undermining US soft power. "America first", points out the political scientist in an interview released in January 2018, "is a policy whose purpose is to make others think of being second, and is having the negative effect of reducing American soft power. Most public opinion polls show that the United States is less attractive to other countries today than it was before Trump" (Bechis, 2018). Even within the United Nations, the American attitude embodied by Ambassador Nikky Haley, is creating a cohesive group of states that resent the new American policy, now called "sharp power".

\section{A NEW ERA}

The sunrise of 1992 marked the end of bipolarity, of that system of economic, military and political relations that had characterized the history of the world since the end of the Second World War; a system of relations founded on the existence of two superpowers, the United States and the Soviet Union, and guaranteed by a nuclear deterrent system, which in the end had preserved the world from a third world war. The Soviet Union imploded as a consequence of the reforms tenaciously desired by Mikhail Gorbachev. The last Soviet leader, soaked in those ideas launched by Nikita Khrushchev in the late fifties that had characterized the years of his formation, had intended to bring his country to a contemporary socialism, able on one hand to ensure itself, that is, the Soviet system, and on the other to really respond to the needs of citizens (Kotkin, 2010). But, contrary to what was expected Soviets did not want a more human socialism, they yearned for a consumer society as it had developed beyond the Iron Curtain. The Soviet Union did not collapse under the burden of indebtedness or what was believed to be a sick economy, it had fallen because it was rejected by the Soviet citizens themselves. And Gorbachev had done nothing but opening the Pandora's vase. With this unexpected event ended forty-seven years of history that had been defined and conditioned by the presence of two equal super powers: according to the definition given by their own former leaders Kennedy and Khrushchev, they were equal in military, economic and political capacity (Benocci, 2010).

In the aftermath of the Soviet collapse we witnessed the end of the idea of a division of the world between good and bad, between capitalists and proponents of the planned economy, between right and left, between proCommunists and pro-Americans; and again, disappeared the need of so many emerging countries to define themselves as a "third block" as opposed to the bipolar system. The economic 
idea of a first, second and third world could have been considered overcome ${ }^{1}$. The world was forced to re-read itself and to understand that it was necessary to start thinking about international relations in a completely different way. The dissolution of the Soviet empire had not only left a geographical vacuum, which would be taken and occupied largely by Germany and with it necessarily by the European Community (Benocci, 2017), it had deprived the majority of intellectuals, observers and Western political leaders of their most important ideological point of reference.

The years between 1993 and 2001, which without doubt can be considered "pioneering", are characterized by the emergence of the idea of a kind of unique thought. The political scientist Francis Fukuyama, who speaks of the end of history, contributes to the emergence of this idea. In fact, with this statement he intends to clarify that a new international system - borrowed from the American model and characterized by a single economic and political system - was emerging or could have been affirmed. After all, the American model was the system that emerged victorious from the bipolar confrontation which in turn had characterized the history of the twentieth century from the end of the Second World War. Ultimately, with the fall of the Soviet "dictatorship" the preconditions were created for the world of the so-called Anglosphere. As Donno (2017) reminds us the Anglosphere "was the center around which a new world commu- nity could develop, a point of connection for the democratic movements of the world and finally a further point of coagulation for the entire West" (p. 16). In the early nineties the idea was that, after the English century, the nineteenth century, and the American short century, the twentieth century, the twenty-first century could be the century of the Anglosphere, founded on the two cardinal principles of individual freedom and of the law, with its primacy of struggle against totalitarianism and statism (p. 23).

Especially in the United States, many people believed it possible. The same American president Clinton came to affirm it publicly, when he invited to enlarge NATO to the countries of Eastern Europe and to former Soviet republics. In 1999, Clinton favored the entry of the Czech Republic, Poland and Hungary into the Atlantic Alliance on the basis of the belief that the United States had won the Cold War and that they were responsible for the reorganization of European and international security. These hasty choices, well highlighted in the following years, would have created the conditions for new international crises. As the political scientist John Mearsheimer states in 2014:

"The most common version says that reason was the containment of Russia, but it is not. The policymakers surrounding Clinton sincerely joined a liberal view of international politics that the democratic institutions of America and Western Europe were the privileged, if not the only, instruments for achieving

\footnotetext{
1 It is important to underline that since the Seventies, following Willy Brandt's report of 1980, the definition of first, second and third world has been largely substituted by that of North and South of the world.
} 
peace and prosperity. If it worked in the West it will also work in Russia, they said. And they said it in good faith, genuinely animated by the desire to extend the model of thought to which they attributed the stability of the West. Not to mention that at that point Russia was a disastrous country, it was not a threat to anyone but to itself, other than containment. The ultimate goal was to involve Moscow in the alliance in some way" (Ferraresi, 2014).

In the nineties, America was so immersed in this idea of promoting its geopolitical theory that it was no longer able to conceive that other countries could adhere to other conceptions. At that point the idea of the end of history by Francis Fukuyama was prevalent: liberal democracy was an inescapable destiny. Russia, on the other hand, remained faithful to the realist doctrine (Ferraresi, 2014).

Moreover, the American president had a good game. Yeltsin's Russia, headed by the newly formed Russian Federation (December 25,1991 ), seemed far from regaining an international role and the Chechen situation was of no help at all ${ }^{2}$. In general, in those years the conflicts, mostly ethnic, and the crises, mostly local, required the intervention of meddling and peace forces; this contributed to confusing the role of UN intervention with that of NATO. The United States of Clinton would not have retreated in front of the need for intervention in crisis areas, thus earning the name of "international policeman". In the same years, many issues that had characterized international relations in previous decades, seemed to find a new composition, which excluded the use of violence. In fact, in Northern Ireland, tormented by the so-called Troubles for decades, it was reached a first and then definitive ceasefire, the Good Friday of 1998; in the Middle East the Arab-Israeli conflict experienced a moment of great pacification thanks to two leaders, Arafat and Rabin, which under the leadership of President Clinton, signed the Oslo Accords in September 1993. Thanks to their efforts, in 1993 both leaders were awarded the Nobel Peace Prize. Finally, the sad and dramatic era of Apartheid ended in South Africa and in 1994 Nelson Mandela was elected president of the Republic. The country faced a complicated phase of normalization and, above all, it emerged from the international isolation to which it had been subjected due to the separation regime. It seemed possible that the soft power promoted by the Anglo-American sphere since the early twentieth century could exert an extraordinary influence in every part of the world. It seemed that a democratic trend could prevail, that the world could be pacified and that the United States could continue to be an essential reference point for any freedom enterprise (Donno, 2017).

\section{A GLOBALIZED SYSTEM}

In the same years, however, the exercise of soft power did not seem to be just the prerogative of nation-states, it rather seemed to become the

2 The crisis in Chechnya started immediately, first with an internal crisis and then subsequently resulted in a real war of independence that lasted for about twenty years (1991-2009). 
prerogative of other important international actors. To understand this aspect, which further complicates the analysis of this decade of profound change, we must let the creator of the term soft power, Joseph Nye explain what was happening: soft power is, according to Nye, the "soft" ability to induce other subjects to adopt a conduct conforming to the wishes of those who exercise the soft power without the use of weapons or economic pressures; in short, the ability to obtain sharing and participation. The inner difficulty in soft power is to maintain a high level of credibility and consistency over time ${ }^{3}$.

It should be emphasized that Nye's happy intuition had in fact allowed a better evaluation and interpretation of the real influence capacity exerted by a single country in the international arena. Soft power experts during the Cold War years were, as Nye pointed out, the United States and the Soviet Union. But during the 1990s, beside the Fukuyama theory of the end of history and of the overcoming of the nation-state, another idea emerged, strongly promoted by Nye himself, according to which the centers of power were now multiple, in some cases very different from the nation-state that until 1992 had dominated the international scene.

In a post-bipolar phase, the concept of soft power was also rooted in subjects quite different from the nation-state, but which by their very economic or social nature were able to exert an important capacity of influence and address at the international level. Therefore, according to Nye himself, soft power actions could be exercised by non-governmental organizations (NGO's), large economic groups, the Holy See, the European Union, but also by terrorist groups such as Al-Qaeda or countries like Saudi Arabia. For example, the latter had successfully tried, over the years, to assert Wahhabism worldwide. It was clear that a profound change in the international forum was in place, now also called to incorporate requests from below and not shared by the major global powers. The signature of the Kyoto Protocol in 1997, that had not found the consensus of the United States, and the great demonstration in Seattle against the World Trade Organization (Wto), which sanctioned the birth of the Anti-Globalization Movement, were the expression of these new global political and social movements (Ceri, 2003; Montagna, 2007; Adamo, 2016).

Throughout those years, along with the transformation experienced by the concept of soft power, a new process of globalization was established, which held within it the embryos of what would be its most tenacious opponents. The changes that were taking place, as we shall see, were interdependent and moved by the large diffusion of digital technologies. Before proceeding with the narration, it is worth remembering that even in the aftermath of the end of the Second World War, and even before

\footnotetext{
3 The term invented by Joseph Nye in 1990, extended the concept of power of an international actor to the field of culture and ideals: a power exerts its capacity to influence in the world not only thanks to its economic or military system, but also through the diffusion of its values and its life system.
} 
its end, the world was seen as a globalized reality. In the political design of men like Roosevelt, the term globalization indicated the creation of an international system suitable for the safeguarding of peace, therefore capable of erasing the limits and risks implicit in the disorder of Versailles. They worked on the construction of a new order based on new global institutions able to solve the problem of maintaining world peace, and rehabilitating the economy from disasters caused by war, in compliance with the American conception: "the creation of a commercial and financial system suitable to act as a framework within which the market economy could give the world the greatest possible prosperity and economic growth in a climate of political and commercial freedom" (Di Nolfo, 1994, p. 586).

Unlike the 1940s, the new globalization was favored by the idea of the spread of the so-called unique thought, but as mentioned earlier it was strongly supported by new technologies, above all the Internet. In these years it was possible to observe a progressive reduction of trade barriers accompanied by a strong reduction in transport costs and communication services. The market became global and multinational companies or corporations were the main drivers of globalization (Barba Navaretti, 2013; Goldstein, 2011; Merton, 2013) ${ }^{4}$. The production of goods and services was no longer confined within the physical and legal boundaries of the nation-state, it could be re- alized everywhere, far beyond the borders of the individual states. Suddenly, the availability of these new technologies made it possible to coordinate activities that were physically distant from each other. This resulted in the fragmentation of production processes and the consequential delocalization of production systems or parts of them to different and distant countries. Without entering into the specific mechanisms of market and finance, it should be remembered that international companies and financial institutions became less and less controllable, increasingly autonomous in their choices and free from the policies of the states. Within the space of just ten years, it was clear that the new globalization would have decreed not an improvement in living conditions at world level but would have created the conditions for ever greater inequalities among workers, states and different economic areas. Many were the voices of protest and dissent against the new global economic process perceived as a danger, since it went far beyond the classical idea of a free market; it not only seemed to act in a condition of lack of state or international controls, but also it ended up damaging the environment and increasing climate changes (Wallach, Sforza, 1999). Many economists would have asked vigorously that this kind of new free trade were put under control; some of them also would have asked economic and political actors to act and reason in terms of fair trade. In those years it became also clear that

4 As Barba Navaretti underlines, until the Second World War only the States managed and owned the resources. After the war other actors, i.e. corporations, began to manage and own resources. Among states there was an important change: at the end of the sixties United States had the leadership of the world market, after twenty years Japan prevailed; nowadays China and India, as well as Brazil, can be considered leaders of the global market. 
while some areas, once embraced the global free market, would have benefited from it, others, less rich in resources or totally deprived, would have been dramatically penalized if not definitively excluded from the global market. Against this process, seen and perceived as the building of an increasingly unequal world, moved the so-called people of Seattle - just mentioned above. Thanks to a globalized communication, daughter of the same new technologies, it would have been constituted and then increasingly organized a global movement, whose main instrument of affirmation was precisely the global information, quite distinct and far from the one advocated by traditional media. This new instrument was the Internet, through which it was (and is also now) possible to organize all around the world events, demonstrations, actions of contrast against the new symbols of global power like G8, wто and FмI (Vitali, 2001).

\section{EUROPEAN UNION IN TROUBLES, CHINA AND HOLY SEE}

As William Keylor claimed in 2003, in his book A World of Nations, the nation-states would continue to play an important role also in the new globalized world. However, it is certain that they were experiencing a phase of profound transformation. Expression of this assumption were in those years the European states that faced the change in a unique and singular way. Although aware of the need to face the new global challenges in the guise of a single political entity, as the European Union could have been, the European countries remained firmly faithful to the idea of the nation-state. So, as a community without international legal status, the European Union (EU) went through the nineties and early 2000s. These years were profoundly difficult for the EU. Its eastern front collapses under the weight of Soviet dissolution and the process of monetary union proceeds with great difficulty. The $\mathrm{EU}$ faces change in its own way, expanding and incorporating Eastern Europe. It also overcomes the difficult knot of the single currency. In this way it responds to several requests, the German one of unification and security, the European Union ones of economic and monetary union, the containment of united Germany, and security of its borders. In this way, the European Community plays an important role: it ends up pacifying the Eastern European countries and reducing the risks of war and crisis emerged along the Danube-Balkan axis. But it was a cyclopean effort, whose consequences are still being paid by Europeans in terms of political and economic difficulties (Benocci, 2017, pp. 154-158). At the beginning of the 2000s the EU was recognized as a civil and a geo-economic power, whose experience was considered replicable in Southeast Asia and Latin America. It is interesting to remember that in the same years Italy experienced the end of its first republic. The country was full involved in the so-called

\footnotetext{
5 Tangentopoli: the use of the term has been affirmed since 1992 following the judicial inquiries carried out by the Magistrature of Milan and subsequently carried out also in other Italian cities, which led to the dissolution of some Italian historical parties, including Democrazia Cristiana (DC) and Partito Socialista Italiano (PSI).
} 
Tangentopoli5. Its political and economic institutions, as well as the entire Italian society, were swept by a tsunami, which cancelled a malfeasance's system and with it fifty years of a system of governance. Italy did not seem to take part in the global change taking place, it did not have the strength, folded in an attempt to save the savable. The Italian political forces, or what was left of them, would have woken up very late to understand that the world had changed, that Europe had changed, that those concepts and terms that had marked the Italian political confrontation throughout the previous decades were now largely outworn. It would have been hard for Italians to identify new issues and find new political guidelines, but the Italian nation-state was still alive.

Now it is not possible to analyze those years without realizing that among the emerging countries, China could have taken on, if desired, a role of fearsome competitor in the eyes of the Americans. It is interesting to remember that, in times of bipolarity, Washington had never underestimated China, constantly requesting the Soviets to avoid China become part of the atomic club, so obliging the Chinese to sign the Non-Proliferation Treaty, which once again was aimed to make permanent the exclusion of Beijing and Bonn from the list of nations capable of holding nuclear weapons. During the pioneering years we are talking about, China emerged as an economic and potentially also a cultural power. In fact, China was able to export capital, technology and labor force at the same time. In a few years it would have been widely recognized as a geo-economic power. It was a member with full rights of the BRIC. Undoubtedly, it was a military power. To put it in terms of power, China seemed to have two of the three elements that constitute an international power: economic and military power. But, unexpectedly, the Asian country tried to act in terms of soft power. For example, like many European countries, it refused armed intervention in conflict areas. Due to this, it was associated not only to the EU, but also to Russia. And it was also clear that China was investing heavily in its own culture: Chinese seemed to be able to benefit from their fascinating traditional culture and their continuous economic successes. Despite this, as Rossi (2013) underlined, China could have not competed yet in terms of culture with Europe and the United States. At the same time China and the United States could have come into conflict if the Chinese had decided to control the seas, to seek military equality in order to control and monitor the commercial and resource supply routes. Another possible area of confrontation between the two countries could have been the African continent. Here, apparently undisturbed, the Chinese were proceeding to the purchase of arable land for future agricultural production.

Another unexpected actor of those troubled years was the Holy See. As we have previously said, Nye inserts the Holy See among the actors who use soft power with great skill. In this specific case, we are dealing with a subject lacking both hard power instruments and an internationally competitive economic system, which makes the instrument of persuasion its main instrument of international dialogue. As Rossi (2013) recalls, the Holy See intervenes in global issues, opposes war, calls for peace among peoples and deals with 
issues of equality and social equity always and exclusively through its encyclicals. It usually intervenes by keeping faith with the principle of freedom of its action and its universal role. But, the historian still observes, the attack on the Twin Towers in 2001 obliged the Church of John Paul II to take a precise orientation: even in the face of Islamic fundamentalism it could not share the idea of the preventive war as advocated by Bush Jr. So, during the second Gulf War, at the very moment when the international community was deeply divided, the Holy See assumed the moral duty to defend international law and the primacy of the UN, stating that inter-religious dialogue could have fought the Islamic fundamentalism. Although it could not avoid the intervention in Iraq, Rossi recalls, the Holy See worked tenaciously in its role of moral persuasion, helping to isolate even more Washington internationally.

\section{THE END OF A UNIQUE THOUGHT}

The idea of being able to proceed along the furrow of a unique thought would have been interrupted dramatically and definitively on September 11, 2001 with the attack on the Twin Towers of New York. The world and, above all, the United States, were forced to awaken. The attack on the Twin Towers undermined the optimism that had led to give priority to soft power (Rossi, 2006, p. 261). In the same years of world globalization a criminal power was born; it was one of the consequences of the political choices made in times of Cold War. It had no restraints and did not recognize limits to its actions. Grown up and fed by the great powers and their allies in Afghanistan, it was challenging the Western countries, their cultural model and their allies. The Twin Towers' attack had unveiled the protagonists of this new kind of international terrorism: the Taliban led by Osama Bin Laden (Magdi, 2001; Guolo, 2001; Romano, 2004) $)^{6}$. These new terrorists, who had their theoretical roots in the violence of the words of Ayatollah Khomeini and in the antiWestern movements that had characterized the seventies in the Middle East and North Africa (Campanini, 2006), were not afraid to deal with that unique thought that seemed to have won the ideological war; in a certain way they rejected and fought tenaciously the idea of globalization that seemed to be able to spread everywhere in the world. Above all, with their criminal and violent actions they obliged the Western world to deal with an idea of risk unknown until that moment. They imposed the exercise of a new reflection. They revealed what till then had remained in the corner and well hidden: the world was not pacified, the risk had not been overcome, the idea of a single gendarme was not feasible. The United States was forced to acknowledge that it possessed an oversized military capacity for the defense of its country alone, but undersized to cope with the new terrorist challenge. But unlike its desire, it was aware that the West was not compact.

\footnotetext{
6 The attacks on the American embassies of Nairobi and Dar es-Salaam (August 7, 1998) and the attack on the Warship Uss Cole, docked in the port of Aden (12 October 2000), had also been linked to Bin Laden.
} 
The United States did not find consensus: its former allies were no more ready to follow Washington unconditionally. As Del Pero (2011) points out, the 11 September's event changed drastically the situation, it nourished a sense of fear and vulnerability destined to justify radical and extreme choices; it ended to alter the internal balance of the American administration by penalizing the most moderate positions (p. 112).

At that time, the United States was led by Bush junior, who had managed to beat the Democratic candidate Al Gore, with a program focused on the fight against the economic crisis and on the recovery of relations with Latin America (Di Ruzza, 2011); a sort of return to normality that assigned a low profile to foreign policy. The terrorist attack completely transformed his government program. Immediately, from the first hours after the terrorist attack, Bush defined the subsequent American reaction as a "war against terror" and moved to win it. Bush called on the democratic world to struggle to export democracy everywhere and to accept the idea of preventive war. It is very interesting to remember that before then the United States had always rejected the idea of a preventive war. For example, on the occasion of the 1956 Suez crisis, Eisenhower had tenaciously opposed the idea advocated by Israel that it could be possible to proceed with acts of preventive war in order to guarantee the security of its territory (Donno, 1998). Del
Pero (2011) still remembers that the total and global nature of the challenge justified the use of any means and the refusal of any constraint to the deployment of power. Internally and internationally, the American administration had to be free to act without legal, geopolitical or economic restraints (p. 113).

In 2001, Bush asked for and obtained from his historical allies the help for an invasion of Afghanistan. Even Schroeder, the Chancellor of Germany, assured and provided the maximum support to USA. It is important to remember that Germany always opposed to being involved in war actions (Benocci, 2017, p. 149). However, after the Operation Enduring Freedom, successfully concluded, some European countries thought they could not proceed anymore along the path outlined by the American president. On the occasion of the second Gulf War in 2003 they denied their help. In the following years, France, Germany, Russia, China would have emphasized their firm opposition to the preventive armed intervention policy inaugurated by the Bush administration. In 2008, at the end of his second term, Bush left a country in economic crisis - the bubble of the subprime had just burst - and the international arena was now characterized by the presence of many actors able to perform a persuasive function, that is, to exercise soft power. Among these, emerged strongly the European Community, Germany, the so-called BRIC Group (Brazil, Russia, India

\footnotetext{
It is clear, that in this case the reference is to Turkey pre-Erdogan and pre-Arab Spring. In the space of a few years, Turkey has moved from being a model of democratic government, cohesive with European and Western values, internationally appreciated, to a dictatorial and repressive model ever closer to forms of Islamic fundamentalism. This is what has seriously endangered Turkey's entry into the EU (Bianchi, 2015; Custodero, \& Gallori, 2016).
} 
and China) and even Turkey ${ }^{7}$. All these countries advocated an idea of unarmed intervention in situations of crisis or conflict. At the same time, they played an important role from the point of view of economic and financial aid to the countries in difficulty. Some of them were committed to the protection of the environment and they fought against climate change. Beside the first ones there were virtuous economic areas, such as the Southeast Asia or the Latin American world. Although the United States remained the only super power, many countries continued to be detractors of the American model. United States still inspired an idea of a country, which thanks to its military and economic power, was intent on building an empire. The anti-Americanism that emerged since the times of Cold War had continued to spread, to strengthen itself, even when the American commitment against Islamic fundamentalism was at most. The United States seemed more alone than ever.

\section{AMERICAN SOLITUDE ${ }^{8}$}

The difficulties faced in those years by the Bush administration are highlighted by many observers and scholars. The primacy of politics, as an art of the possible, should have reduced the causes of social instability, the risks of conflicts and wars through the creation of a new world order; a world, as previously stated, based on the American model or the so-called Anglosphere. At the beginning of the 2000s this was a bet that could no longer be postponed, a bet of a political and cultural nature since the threats were no longer ideological in nature, as they had been in the so-called short century, but they were the result of a conflict between civilization, a sort of cultural incompatibility, before than political or economic. But the United States seemed not to be able to pursue this goal any more. Hence the dilemma experienced by the American leadership: by many invoked in its role as a unique gendarme, but also strongly contested because of its economic and military policies (Sansonetti, 1996). While someone shared American politics, many others rejected it, attributing to USA instead an aggressive tendency, ready to force the hand; ultimately an unbearable conditioning.

It follows the complex nature of the concept of American empire (Del Pero, 2008). In fact, the international situation and, above all, the status of the United States at the time could not guarantee a true American empire: it would have been devoid of two essential resources: a military and economic power of constraint to maintain the exploitation's level of the planet and an ideological universalism that could not fail trying to meet people's desire to be treated equally; in fact, the latter sought an equality on which to build a true peace and lasting prosperity (Rossi, 2013, p. 9). Surely, it had not helped the Americans military and economic overexposure of the first years of the new century. Although justified by the growth of the global threat, many observers criticized the unilateralism of Bush Jr. (Prestowitz, 2003; Ramasso Valacca, 2002). Despite this, the country had

8 The term is used by Romero in his article Solitudine americana (2011).

Revista OASIS, ISSN: 1657-7558, E-ISSN: 2346-2132, No 28, Julio-Diciembre de 2018, pp. 7-24 
assumed the role of defender of the free and democratic world. Other factors also contributed to isolate the USA. Bush insensitivity towards the needs of the allies, his excessive support for Israel, his skepticism towards international institutions. Also, his imperial pretensions and the overvaluation of military force, his propensity to neglect the soft power in all its manifestations contributed to deprive USA of allied support. In those years Bush seemed to have forgot, paradoxically, that US nationalism should not have evoked the notion of ethnic superiority, but the belief in the primacy of democratic ideals (Rossi, 2013, p. 7). It is indisputable that the United States was not and will not be in the future a power intent on creating an empire. They are not able to do it militarily or economically, since they do not hold the economic resources they need, starting with the control of the oil routes. Returning to that decade of transition, as Kupchan (2003) states, the United States had shown they had not understood the change then taking place. As Romero (2011) remembers, Washington had articulated its action on the idea of a new international order, founded on an international community of a cooperative nature, supported by an ever-expanding liberal model. In the belief of being an indispensable power, the USA had not understood that the nineties, characterized by the absence of the
Cold War, were suitable for experimentation of individual states or communities of states, as well as of groups or movements, also of violent nature. Without a precise or at least sufficient understanding of that time, they simply had tried to cope with the new terrorist threat, reviving an idea of hard power, now outdated and unacceptable.

In the same years, Washington began to experience a progressive economic dependence from the rest of the world; it was also aware to be perceived less and less as a genuine defender of the democratic and liberal order (Chomsky, 2013) ${ }^{9}$. It was opinion of many observers that Washington had to proceed along a path of new sharing with Europe and Japan, those countries that had shared for a long time the same values and actions with the United States. It would have been the new American administration, led by Obama, to try to create a new platform of dialogue with the former allies, taking into account, unlike what done by Bush, the differences between the American model and the Western European one, as established in the transition years.

\section{OBAMA AND THE EXERCISE OF SOFT POWER}

Barak Obama's arrival in the White House, greeted even with a Nobel Prize for the "good

9 As pointed out by Sacco (2008), the United States presented itself as a country paralyzed by the rhetoric of the great individualistic and pioneering society, of which the Americans are impregnated to the tip of their hair. However, the ideology that in the nineteenth century had made possible the conquest and economic exploitation of the immense spaces of the Middle and the Far West, in the twentieth century, led to specular opposed results. Not only, it has led the destruction of the natural patrimony (the great resource of the past) and the atomization of individuals and the dissolution of the social bond. That is to say a situation that, in the political field, is concretized in the inability to elaborate a great collective project suited to the times and challenges of the 21 st century. 
intentions" in October $2009^{10}$, let hope for a re-consolidation of the West around the USA, at that moment not at all obvious. Even before his settlement, the Democratic candidate had well delineated his role in foreign policy: the renunciation of atomic weapons, a policy of opened hand to Islam and a policy of friendship with the Russians, as well as an invitation to work for autonomy and independence of peoples of the African continent. It was clear that the new US administration led by Obama would not have kept a low profile in foreign policy and, above all, would have distinguished itself from that of President Bush. Obama was ready to concretely re-launch the US world leadership without the fear of shaking hands also with possible enemies. He seemed to launch a new American course and within it strengthen the existing multilateral alliances. Obama seemed to run for the role of bearer of a new idea about the United States in the world, which went beyond the attestation of exceptionalism; the American president identified the renewed and growing alliances and coalitions as an engine, a world laboratory of ideas (Valli, 2016; Nougayréde, 2016; Zelizer, 2018; Maas, 2018). Despite the good intentions, the outbreak of the Arab Spring in 2010, which would have long inflamed the Middle East and North Africa, the return to the international scene of the Russian Bear under the leadership of Putin, which opened new and still unexplored international scenarios and, not least, the serious and over ten-year global economic crisis would have partially compromised Obama's foreign policy goals. Nevertheless, not a few were the successes achieved by the Obama administration, even against strong internal political opposition. The President responded to the challenges of his time, primarily trying to heal the misunderstandings generated by the previous Bush administration in the field of relations with the European countries. He returned to an idea of strong cooperation between the United States and Western Europe, espousing some of the goals pursued by the EU in recent years: Obama's great commitment to health, work and youth policies. He experimented a decisive intervention of the state on the financial and banking system and, finally, showed and promoted an unexpected American interest for the protection of the Earth and the fight against climate changes. In 2015, the American signature of the Paris cop 21 agreement was hailed worldwide; for the first time, the United States was committed to reducing polluting emissions into the atmosphere. It was not the signing of the Kyoto Protocol but a first step, a solid American commitment to the protection of the Earth, which also involved the Chinese. "This is not a battle that every single country, however powerful, can do alone", Obama added, "one day we can see all this when we finally decide to save the planet" ("Cop21, Cina e usA ratificano l'accordo di Parigi sul clima”, 2016).

In foreign policy, the Obama administration marked three important successes: the capture and consequent killing of Osama Bin

\footnotetext{
10 Thanks to Obama, the Nobel Prize Committee declared, the United States is now playing a more constructive role on major issues such as climate, democracy and civil rights (Beltramini, 2009).
} 
Laden in 2011, which healed - or attempted to heal - the wound of September 11, 2001; the start of relations with $\mathrm{Cuba}^{11}$ and the signing of the Vienna Agreements with Iran in 2015 $5^{[12]}$. This latter was an important success, because with it the Iranians renounced nuclear power for military purposes. It had a second important consequence, it determined a greater isolation of North Korea, the last of the rogue states of the Bush era. As it was announced by the first Obama's speeches, the hard power of the Bush era in the Obama's modus operandi remained the last of the options.

However, this kind of foreign policy, founded in primis on alliances and partnerships (a sort of pioneering smart power), has ended to assign to Obama presidency the role of weak government, mostly in the struggle against the Islamic fundamentalism, which in turn continued to hit mortally the Western world and to build successfully the Islamic State (IS) in Iraqi-Syrian territory.

\section{IN THE ERA OF TRUMP'S SHARP POWER: SOME REFLECTIONS}

Approaching the conclusion of this paper, it is possible to state that with the end of the bipolar system, power has assumed and is still taking different forms, often incomplete, mostly unable to achieve results in the long period, but able to bring actions and reactions in the short period. What emerges with great clarity is the fact that if in the bipolar era the different states could freely experiment themselves with forms of soft power - since the defense burden was entirely in the hands of the two superpowers - from the last decade of the 20th century, particularly in the aftermath of the attack on the Twin Towers, members of the international community frequently had had to question themselves on the subject of defense. But, surprisingly, even in the face of a growing risk, such as that represented by Islamic fundamentalism, many European and Western states have continued to claim autonomy of behavior and judgment, declining any military involvement, once again confident that they could continue to rely on the military capacity of the USA.

In this behavior lies the failure of the idea that the end of the bipolar system would have given rise to a global society conformed to the Anglo-American model. This idea has sunk under the weight of terrorism, on one hand, and the emergence of the new social and eco-

11 Obama's historic trip to Cuba in 2016 was the result of the thaw between the US president and the Cuban leader Raul Castro. The two statesmen decided to work for the normalization of relations between their two countries. After the re-opening of the respective embassies, an agreement had been made to restore commercial flights between the US and Cuba for the first time in 50 years (Di Ruzza, 2011).

12 "Thanks to the agreement", Obama said, "the international community will be able to verify that Iran does not develop atomic weapon, Tehran will be deprived of 98 percent of its current enriched uranium reserves, an agreement that is not based on trust but on verification. If Iran violates the agreement all sanctions will be restored and there will be serious consequences. No agreement would have meant no limits to Iran's nuclear program. The United States will maintain sanctions against Iran linked to the violation of human rights" ("Nucleare Iran, è accordo: via le sanzioni, controllo internazionale. Ira Israele”, 2015). 
nomic models in Asia and Latin America, on the other. Much has contributed the European Community, which, although in difficulty, has continued to claim and promote its social and economic model and its policies in favor of the protection of the Earth, and above all, its constant refusal to assume responsibility for military intervention. It has prevailed the European historic, cultural and economic model, and this at detriment of the American model (Obama's one too), that Europeans always consider different from theirs. It is clear, that this imposes now more than ever an evaluation of the international status of the European Community (the unresolved problem of overcoming the Nation-State) and of its military commitment.

It is evident that the presence of Donald Trump at the White House, who seems to delegate only to the hard power the task of "make America great again", has contributed strongly to the European debate. Trump, however, is not the only person to have such a belief. As Hillen (2016) recalls, the scientist Cohen goes on to define that world and its geopolitical setting: America has a good hand to play. It is a vigorous, prosperous, and inventive nation blessed by wealth, demography, geopolitics, natural resources, and other enduring sources of competitive advantages. But America's advantages and interests cannot be secured without a sober appreciation for the necessity of hard power (Cohen, 2016). After the election of Donald Trump, the author of Shock Economy Naomi Klein has talked of shock politics. As she underlines, also Kellyanne Conway, Trump's collaborator, defines the American new era as a shock to the system. Not only, at international level Trump uses the menace of the military American power, at internal level he simply menaces to act and rule through continuous shocks. In this way it is possible to define his power as a sharp power. But his policy is largely feared both in America and Europe. As recalled at the beginning of this work, Nye has recently affirmed that Donald Trump's policy is having a serious negative effect of reducing American soft power. In fact, as he explains, "sharp power is just a new term to indicate what we once called information war, which existed for decades, and in particular since the 1930s and during the Cold War. The information war will not replace the ability to attract other countries through soft power, which played a key role in the success of the United States and in the stability of their alliances" (Bechis, 2018).

But if we look closely at the actions taken by Donald Trump in his first year of government, we see that he acts between nationalism and neoliberalism: an external nationalism (the duties on steel and aluminium, those on Chinese products), an internal neoliberalism (tax reduction, complete liberalization of weapons, reductions in good environmental practices, reductions in privacy, attack on Obama Care). If we look at his approach to North Korea, to the NAFTA agreement, and also to the Iranian nuclear agreement, we realize that the concept of "enemy friend" loses its meaning: after all, India "is a true friend" until it doesn't claim the maintenance of the H-1B (Rossi, 2017), as well as the Russia of Putin has recently been recognized by Trump extraneous to Russiagate. If European countries, as well as the BIS (Bank for International Settlements), are seriously worried about the new protectionist American 
policy, they are also aware that "Trump's words are an instrument for mediation but not a real menace" (Sarcina, 2018). What is certain is that Trump will continue in the wake of sharp power in the mid-term or, at least, until the polls show him as the winner, at least in the Republican field. Recently, Gallup revealed that $90 \%$ of Republican electors agree with the President.

In conclusion it is possible to affirm that twenty-five years after the end of the bipolar phase the international system is still in profound evolution and the theses about the decline of democracies are arousing further insecurity. Fukuyama himself has recently stated that history is re-started as democracies are at risk:

"Democracy has legitimacy problems and gets little popular support in recent years because many democracies are perceived as weak. Every government has to make difficult decisions, guarantee basic rights and services to citizens and it cannot. The populism that crosses Western countries and advanced economics is the son of this frustration" (Iaccarino, 2017).

Surely it is no longer possible, as Keylor widely argued, to talk about the end of the nationstate, that today results to be more than ever profoundly necessary. At the same time, it will not be possible in the forthcoming years, for any power, nation-state or community of states, to face up to concept of risk (now so variegated) without a form of power necessarily based on both elements of soft and hard power.

\section{REFERENCE LIST}

Adamo, P. (2016). L'anarchismo americano nel Novecento. Da Emma Goldman ai Black Bloc. Milano: FrancoAngeli.

Barba Navaretti, G. (2013). Le multinazionali e il mercato globale. Capire l'Economia. Roma: Gruppo Editorale L'Espresso.

Baritono, R. \& Vezzosi, E. (ed.). (2011). Oltre il secolo americano. Gli Stati Uniti prima e dopo l'11 settembre. Roma: Carocci Editore.

Bechis, F. (2018, 12 gennaio). Così Trump sta minando il soft power Usa. Intervista a Joseph Nye. AirPress. Available from: http://www.airpressonline.it/

Beltramini, E. (2009, 13 ottobre). Obama, perché si è meritato il Nobel. Limes. Available from: http:// www.limesonline.com/

Benocci, B. (2010). Due Presidenti e un'occasione mancata. Kennedy e Kruscev e la fine della guerra fredda. Salerno: Plectica.

Benocci, B. (2017). La Germania necessaria. L'emergere di una nuova leading power tra potenza economica e modello culturale. Milano: FrancoAngeli.

Benocci, B. (2017). La fine della (in)sostenibile corsa. Gli stati europei tra rigido neoliberismo e salvaguardia del welfare (2007-2017). Eunomia, VI n.s., n.1, 61-90. Doi: 10.1285/i22808949a6n1p61

Bianchi, F. (2015, 3 aprile). La nuova Turchia di Erdogan: ipermaschilista e con il Corano in mano. L'Espresso. Available from: http://espresso. repubblica.it/

Brandt, W. (1980). North-South: A Programme for Survival: Report at the Independent Commission on International Development Issues. London: Pan Books.

Campanini, M. (2006). Storia del Medio Oriente. Bologna: Il Mulino. 
Campanini, M. \& Mezran K. (2007). Arcipelago Islam. Bari: Laterza.

Ceri, P. (2003). La democrazia dei movimenti. Come decidono i noglobal. Soveria Mannelli: Rubbettino.

Cohen, E.A. (2016). The Big Stick: The Limits of Soft Power and the Necessity of Military Force. New York: Basic Books.

Colombo, F. (2017). Trump Power. Roma: Paper First.

Cop21, Cina e Usa ratificano l'accordo di Parigi sul clima. (2016, 3 settembre). R.it. Available from: http://www.repubblica.it/

Custodero, A. \& Gallori P. (2016, 18 luglio). Turchia, Erdogan verso il sì alla pena di morte. UE: "così non entra in Europa”. R.it. Available from: http:// www.repubblica.it/

Chomsky, N. (2013). Sistemi di potere. Firenze: Ponte alle Grazie.

David, C-P. \& Ramel F. (2003). The Bush Administration's Image of Europe: from Ambivalence to Rigidity. The International Journal of Peace Studies, 8, 1.

Available from: http://www.gmu.edu/programs/icar/ ijps/index.htm

Del Pero, M. (2008). Libertà e impero. Gli Stati Uniti e il mondo 1776-2006. Bari: Laterza.

-(2011). La politica estera prima e dopo l'11 settembre. In Baritono, R. \& Vezzosi, E. (ed.). Oltre il secolo americano. Gli Stati Uniti prima e dopo l'11 settembre (pp. 107-120). Roma: Carocci Editore.

Di Nolfo, E. (1994). Storia delle relazioni internazionali, 1918-1992. Bari: Laterza.

Di Ruzza, M. (2011). L’America Latina sulla scena globale. Soveria Mannelli: Rubbettino.

Donno, A. (2017). Anglo-Saxonism o Anglosfera: note sul soft power americano nel Novecento, StoriaLibera, Anno III, n. 6, 11-33. Available from: http://www.storialibera.it/
-(1998). Ombre di guerra fredda. Gli Stati Uniti nel Medio Oriente durante gli anni di Eisenhower (19531961). Napoli: Esi.

Ferraresi, M. (2014, 28 settembre). Un altro mondo è possibile e c'è già. È la Russia di Vladimir Putin, anche se l'Occidente si rifiuta di capirlo. Tempi. Available from: http://www.tempi.it/

Gelvin, J. (2015). The Arab Uprising. Oxford: Oxford University Press.

Goldstein, A. (2011). Bric, Brasile, Russia, India, Cina alla guida dell'economia globale. Bologna: Il Mulino.

Guolo, R. (2001). Osama Bin Laden e il partito di Dio, La guerra del terrore, Limes, 2, 99-106.

Hillen, J. (2016, 15 dicembre). The Return of Hard Power. War on the Rocks. Available from: http:// warontherocks.com/

Iaccarino, M.A.G. (2017, 5 marzo). La storia è reiniziata perché la democrazia ormai non basta più. il Fatto quotidiano. Available from: http:// ilfattoquotidiano.it/

Keylor, W.R. (2007). Un mondo di nazioni. L'ordine internazionale dopo il 1945. Milano: Guerini Scientifica.

Klein, N. (2017). Shock Politics. Milano: Feltrinelli.

Klein, N. (2007). Shock Economy. Milano: Rizzoli.

Kotkin, S. (2010). A un passo dall'Apocalisse. Il collasso sovietico 1970-2000. Viella, Roma, 2010.

Kupchan, C.A. (2003). La fine dell'era americana. Politica estera americana e geopolitica nel ventunesimo secolo. Milano: Vita e Pensiero.

L'immagine dell'Europa è a rischio. (2012, 11 giugno). Cronache Internazionali. Available from: http:// www.cronacheinternazionali.com/

Magdi, A. (2001). Come funziona la rete di Bin Laden, La guerra del terrore, Limes, 2, 81-85. 
Maas, M. (2018). The World Views of the Obama Era. From Hope to Disillusion. Basingstoke: Palgrave MacMillan.

Mearsheimer, J.J. (2014, settembre/ottobre). Why the Ukraine Crisis is the West's Fault. The Liberal Delusions that Provoked Putin. Foreign Affairs. Available from: http://www.foreignaffairs.com/

Merton, R. (2013). La Borsa nel sistema economico globale. Capire l'economia. Roma: Gruppo Editoriale L'Espresso.

Montagna, N. (2007). I movimenti sociali e le mobilitazioni globali. Temi processi e strutture organizzative. Milano: FrancoAngeli.

Nye, J. (1990). Bound to lead. The Changing Nature of American Power. New York: Basic Books.

Nougayréde, N. (2016, 18 novembre). Europe will miss Barack Obama. But maybe he did not care for us. Available from: The Guardian. http://www. theguardian.com/

Nucleare Iran, è accordo: via le sanzioni, controllo internazionale. Ira Israele. (2015, 14 luglio). R.it. Available from: http://www.repubblica.it/

Prestowitz, C. (2003). Stato canaglia. La follia dell'unilateralismo americano. Roma: Fazi.

Raffone, P. (2011, 6 dicembre). Dal Medio Oriente al Middle West, Limesonline. Available from: http:// www.limesonline.com/

Ramasso Valacca, A. (2002), Il cosiddetto unilateralismo americano. Affari Sociali Internazionali, 4, 17-21.

Romano, S. (2004). Anatomia del terrore. Corriere della Sera, Milano: RCS.
Romero, F. (2011). Solitudine americana. In Baritono, R. \& Vezzosi, E. (ed.). Oltre il secolo americano. Gli Stati Uniti prima e dopo l'11 settembre (pp. 29-44). Roma: Carocci Editore.

Rossi, E. (2016, 26 giugno). Usa e India, cosa divide e cosa unisce Trump e Modi. f. Formiche. Available from: http://www.formiche.it

Rossi, L. (2013). Transizioni. Forme di potere in età contemporanea. Soveria Mannelli: Rubbettino.

Rossi, L. (2006). Le relazioni internazionali: alcuni casi di studio. Salerno: Plectica.

Sarcina, G. (2018, 15 giugno). Trump: nuovi dazi. La Cina risponde. La guerra commerciale parte a luglio. Corriere della sera. Available from: http:// www.corriere.it

Sacco, G. (2008). Dopo la globalizzazione, Progetto Obama, Limes, 6, 75-87.

Sansonetti, P. (1996). I due volti dell'America. Gli Stati Uniti tra capitalismo selvaggio e stato sociale, Roma: Editori Riuniti.

Valli, B. (2016, 30 ottobre). Obama e l'Europa: storia di un rimpianto. L'Espresso. Available from: http:// espresso.repubblica.it/

Vitali, F. (2001). I popoli di Seattle. Vita e morte dei gruppi antiglobalizzazione ai tempi di internet, Limes, 3, 19-36.

Wallach, L. \& Sforza, M. (1999). wто. Tutto quello che non hanno mai detto sul commercio globale. Milano: Feltrinelli.

Zelizer, J.E. (2018). The presidency of Barack Obama. A First Historical Assessment. Princeton: Princeton University. 